\title{
SocArXiv
}

Preprint : April 17, 2019

\section{Diversity Discourses: Moral, Ethical and Pragmatic Reasoning in the Swedish Immigration and Integration Debate, 1968-1975 and 1991-1995}

\author{
Carly Elizabeth Schall \\ Indiana University Purdue University - Indianapolis
}

\begin{abstract}
This article seeks to understand how values enter into political discourse via justification and how those values are negotiated over time. The article maps out the terrain of diversity discourses, both as a specific type of discourse and as an example of ethical, moral and pragmatic modes of argumentation. The author examines Swedish "diversity discourses" in the periods of 1968-1975 and 1991-1995 in an effort to tease out the pragmatic, moral and ethical aspects of these discourses. Diversity discourses are defined as discourses regarding how much and what kind of diversity is acceptable or desireable in a society, as well as how such diversity should be handled. I find that values, both contextually-dependent ethical values and universal moral values, rather than being "prior" to politics, arise out of the intersection of pragmatic, ethical and moral discourses. What is moral and ethical, then is colored by the particular nexus of moral, ethical and pragmatic concerns such that what is acceptable at one particular time and location, may be unacceptable in another, even coming from the same actors with the same ideological commitments. Shifts in the ethical/moral modes of justification, then, lead to shifts in who is included in a democratic community.
\end{abstract}

Keywords: Habermas, civil repair, immigration, morality, values, Sweden.

\section{Introduction}

In 1993, journalist Jesus Alcala wrote in regards to a developing refugee crisis, that "Some day, we will have to face the question of what would be most devastating for us to lose, both as individuals and as a society: our material welfare or our morals?"1 In so doing, he set up moral and pragmatic concerns in the immigration/integration debates as diametrically opposed. What was moral could not be pragmatic and what was pragmatic could not be moral. Yet, that 'morals' and 'pragmatics' should be opposed is not a foregone conclusion. 
Indeed, even the sticky territory of immigration and integration discourse has sometimes been characterized by harmony between the two types of reasoning. This article draws on Jurgen Habermas's $(1996,1993)$ typology of moral, ethical and pragmatic discourses in order to understand how processes of justification create space for "values" (both ethical and moral) in political discourse, and how those values are negotiated.

The examination of "diversity discourses" - defined here as discourses regarding how much and what kind of diversity is acceptable/desirable in a society, as well as how such diversity should be handled - is well-suited to the task of teasing out the functioning of morality, ethics and pragmatism in politics and civil society. For one, all three types of argumentation are present in such discourses, and none of the three tends to dominate. It is also true that actors participating in this discourse tend to be sensitive to the complementarity or, alternatively, antagonisms between the different types of discourse - as quotes like the one above demonstrate. Finally, debates on diversity provide multiple dimensions on which to examine moral, ethical and pragmatic reasoning, as well as a multiplicity of contexts, even within a single national case. This multiplicity provides a rich field for examining the extent of moral, ethical and pragmatic reasoning. In turn, Habermas's typology provides a potentially fruitful theoretic and conceptual lens for understanding diversity itself.

As such, this article has two goals:

1. To map out the terrain of diversity discourses, both as a specific type of discourse, and as an example of ethical, moral and pragmatic modes of argumentation

2. To better understand the processes by which political discourses become "moral" or "ethical" and the processes by which such forms of argumentation are "overridden" by pragmatics.

In order to do so, the case of Swedish discourses on migration and integration are examined in two time periods: 1968 and 1975, and 1991 and 1995. The article proceeds in three stages. The first is a theoretical and conceptual mapping of diversity discourses as "ideal types." The second stage is a description and categorization of popular press passages from each of the two time periods, focusing on the ethical, moral and pragmatic dimensions of such utterances. The third is a process-focused synthesis of the theoretic/conceptual mapping and the empirical case study.

\subsection{Moral, Ethical and Pragmatic Reasoning}

Habermas $(1993,1996)$ argues that understanding the justifications that actors in the public sphere give provides key insights into the process of communicative action through which democracy becomes possible. He argues, as well, that the unfolding of ethical discourses, their intersection with moral discourses, and the process of pragmatic negotiation are key to the development of "collective identities" (Habermas, 1993, p. 16; see also Habermas, 1994 and Cooke, 1997 specifically on ethical pluralism). In other words, the ways in which negotiation occurs, and the process of justification, as a way of appealing to common grounds to make our positions legible and acceptable to others (see Boltanski and Thévenot, 2006), help us to understand the way democratic politics work and the way that political communities acquire their specific dimensions. I would add that attention to these processes also helps us to understand how values, specifically, function in a democracy. In the service of such a mission, 
Habermas $(1993,1996)$ draws a line between three types of reasoning: pragmatic reasoning, moral reasoning, and ethical reasoning.

Pragmatic discourses are those that describe an attitude or course of action through appeals to means-ends rationality, dependent on a logic of problem solving. Pragmatic reasoning is applied to situations where one must balance competing interests. Pragmatic discourses demand compromise and negotiation by their very nature. The reference group for pragmatic discourse is quite narrow, involving only the affected parties - the "social or subcultural groups involved in negotiation"(Habermas, 1996, p. 108). Pragmatic discourses prescribe specific courses of action, with reference to the likely or purported results of said actions.

Moral discourses are those that describe an attitude or course of action as "right" through appealing to a set of values purported to be universal. The reference group for moral discourse is considerably wider than pragmatic reasoning, in theory it encompasses all of humanity (Habermas, 1994). Habermas (1996), writes: "In contrast to ethical deliberations, which are oriented to the telos of my/our own good (or not misspent) life, moral deliberations require a perspective freed from all egocentrism or ethnocentrism" (p. 97). Thus, while we can conceive of an "American ethics" or a "Swedish ethics," there can be no such thing as "American morality" or "Swedish morality." Note that just because moral discourses reach towards universality, this does not mean that there is a single moral code. For instance, "Christian morality" purports to apply to the entire human community, yet there are many who do not consider themselves as beholden to Christian morality. ${ }^{2}$ "Morality" and "moral discourse" serve an important function in guiding discourse overall, in that moral discourse set limits for legitimate debate, and create boundaries within which ethical pluralities can potentially flourish.

Ethical discourses are those that describe an attitude or course of action as "right" through appealing to a set of context- or situation-dependent values. Ethical discourses have as a reference group the specific community to which one is speaking. Ethical reasoning is "supposed to express an authentic, collective self-understanding" (Habermas, 1996, p. 108). "Research ethics," for instance, create attitudes and/or behaviors that are consistent with a certain set of values about things like data falsification and treatment of human subjects that are specific to researchers. Modernity has, as a condition, a plurality of ethical orientations, and a corresponding plurality of collective identities. Habermas (1996) argues that under these conditions, ethics can be likened to "liability for one's own existence" (p. 96). He also argues that it is this condition of modernity that makes ethical discourses possible and separate from moral discourses:

To the extent that collective identities can develop only in the fragile, dynamic and fuzzy shape of a decentered, even fragmentary public consciousness, ethicalpolitical discourse that reaches into the depths have become both possible and unavoidable (Habermas, 1996, p. 97).

Unlike morality, which tends to offer only very general instructions and justifications, ethical discourses are capable of offering more specific courses of action.

The line between moral and ethical discourses, despite Habermas's attempt to delineate them definitively, remains blurry, both conceptually and practically. The practical difference is often one of emphasis and degree. Morality tends to produce stronger boundaries, boundaries that are seen as crucially important to the humanity of those classified. Alexander (2006), 
for instance, points to the fundamental moral binaries of civil/uncivil as determinative of a person (or group's) right to membership in society. A person who does not scrupulously follow research ethics, for instance, may be ethically suspect in their field, but does not lose their humanity. Yet, if violations of research ethics also violate deeply held moral injunctions - like those against dishonesty or cruelty - a person may be seen not just as a poor researcher, but as an immoral monster.

Efforts to negotiate ethical plurality within moral boundaries often takes the form of seeking the correct level of abstraction at which all parties can agree. As cultural actors work to reach agreement in order to coordinate action, they seek "higher common principles" on which all parties can agree (Boltanski and Thévenot, 2006) - in other words they move from the pole of specificity represented by ethics towards an increasingly "universal" moral pole. As actors move towards agreement, the principles that agreement rest on must be justified, which Boltanski and Thévenot (2006) argue entails a form of justice as these higher level, more general (moral) principles become bases for agreed-upon judgements about behaviors or people. We can see this logic in, e.g., framing processes by which the correct level of abstraction/specification in order to inspire social movement mobilization (Benford and Snow, 2000). We can also see it in calls for 'big picture' thinking to solve social ills; for instance, Lamont's (2017) call to not solve inequality by tinkering with levels of government redistribution (a matter of economic and political ethics) but by shifting moral boundaries in order to "extend cultural membership to the largest number by promoting ways of living that are not fully organized around the principle of profit maximation" (Lamont, 2017: 21). Note that I describe these as "ideal types" (Weber, 1949). This is because most discourses are not of all one type or another, but blend types of argumentation. The boundary between moral an ethical discourse is particularly porous because it rests on a distinction between universalism and particularism, which may itself shift, with context (see, also, Cooke, 1997 on this). At the same time, ethical arguments often rely on convictions that rest ultimately on a "morality" that is at least presumed to be universal in some sense (e.g. the rules for the ethical treatment of refugees rest ultimately on a moral appreciation for universal human rights). Pragmatism, too, assumes that certain goals are worthwhile (e.g. accrual of tax-revenues, maintenance of social order), and these goals may be primarily defensible through appeals to morality and/or ethics (pragmatic actions may be, in Weber's term, value rational rather than instrumentally rational). Indeed, on occasion a commitment to pragmatism may take on a moral or ethical cast, such as in the case of an ideology of utilitarianism (see, e.g. Bentham, 1907; Riley, 1990). Yet, ideal types remain useful as tools for analysis, both in general and in this specific case. In general, as Weber (1949) has pointed out, in that they provide categorizations that are generalized enough to allow for comparisons between cases, and specific enough to provide concrete guides for analysis.

Specifically, the ideal types used here: moral, ethical and pragmatic, are useful in that they describe a set of actually existing categories that actors are cognizant of and may consciously shape their discourse to fit into, even if they do so imperfectly. In other words, these categories are categories of practice for actors, but that have a history of being used as categories of analysis. These can be productively used in social scientific analysis so long as one is careful to be aware of the sense in which one is using the word (i.e. actors are not always using "moral" reasoning even when they use the words "moral" themselves). Yet the overlapping, fuzzy lines between all three categories, but in particular moral and ethical reasoning create practical difficulties in the operationalization of these concepts, and the 
value difficulties that arise for researchers themselves in deciding what counts as a higher order moral principle complicate things still further (see, e.g. Abend, 2008 for the pitfalls and promises of a sociology of morality). It is useful to think of ethics and morals as opposite poles of specificity/generality and be attentive to the process of justification via the seeking of common principles that Boltanski and Thévenot (2006) claim as their basis for their conception of justice. It is, therefore, necessary to be sensitive to contextual factors when classifying statements, and to simply classify things as moral/ethical when those contextual factors fail to provide enough direction.

It is also true that it is necessary to talk about what is "immoral," "unethical" or "impractical" when one is discussing "morality," "ethics" and "pragmatics." In other words, these are categories that have negatives as well as positives, and, indeed the process by which something, which was previously moral becomes immoral or practical impractical, in the eyes of a specific society is important. Alexander (2006), addresses this in his discussion of the process of "civil repair" or the process by which what was once "uncivil" becomes (re-)integrated into the "civil sphere" - a process which may occur through the de-stigmatization of certain characteristics or the individuals who bear those characteristics. I would argue, as well, that a "civil repair" of sorts that may rehabilitate "uncivil" (or "immoral" or "unethical") discourse, works through the de-stigmatization of certain modes of justification. This process, which can occur at the interstices of previously undefined ethical/moral/pragmatic categories or in the meeting of contradictory ethical/moral/pragmatic justifications, may be just where new value orientations enter political discourse. It is also true, as Swidler (1986) points out that crises - unsettled times - make ideologies, and, perhaps by extension moralities, more visible and concrete, making them ideal times to study the shifts between these modes of justification (Boltanski and Thévenot, 1999 also make the point that justification is more urgent when things are going wrong). Thus studying the interweaving of the three above types of discourses in times of crisis may aid us in locating these interstices and/or contradictions.

The advantage of such an approach - looking for contradictions and 'gaps' that arise out of the process of negotiation over the meanings of political discourses/action - is clear. For one, such an approach does not assume that value orientations are in any sense "prior" to politics, as some literature assumes (e.g. Heilbroner and Milberg 1995). ${ }^{3}$ It also helps us to see how "political culture" - the "the matrix of meanings embodied in expressive symbols, practices, and beliefs that constitute ordinary politics in a bounded collectivity" (Berezin, 1997, p. 364)feeds back into moral and ethical commitments that exist outside the political realm, thereby helping, perhaps, to bridge the gap between work on "political culture" and "politics and culture" as Berezin (1997) exhorts us to do. At the same time, bringing Habermas's typology of justifications into the study of values and politics allows us to conceptualize different kinds of values with different levels of negotiability and ambiguity. The well-documented idea that cultural hegemony may delimit a space of competitive antagonisms within democratic discourse (Riley, 2010; see also Laitin, 1986 on 'symbolic frameworks') is reflected, in this typology, by the structuring capacity of 'moral discourse.' However, the identification of valuedriven, but contextually-differentiated ethical discourse afforded by Habermas's typology gives us space to explore the negotiability of 'values' in the civil sphere.

Finally, while moralities purport to be universal, there are national repertoires of morality that structure discourses. Skarpenes, Sakslind and Hestholm (2016), for instance, contrast French republicanism, US Americanism and Norwegian egalitarianism as higher order value structures that configure the values commitments of inhabitants of those countries. These are 
conceived as moral structures because they are seen as providing universal standards of good and bad, despite their apparent national specificity. In the empirical case presented here, it is worthwhile to consider the particular morality that structures Swedish understandings of purportedly universal values. This tension of particularity/universality can be viewed, especially through the lens of Sweden's self-image as a "moral superpower" (see Björkdahl, 2007).

\subsection{Mapping Out Diversity Discourses}

Many of the concepts underlying our discussions of diversity are, in fact, notoriously negotiable and ambiguous. Just think of the multiple definitions of "multiculturalism" espoused by scholars and lay people alike (Schall, 2014). Lay people often conceive of multiculturalism as the presence of simple diversity alone, while scholars may assign to the word a range of meanings, from a "politics of recognition" (Taylor, 1994).to a call for minority rights (Kymlicka, 1995) to a national identity that has appreciation for difference at its core (Alexander, 2001). Similar problems plague other conceptions of diversity and diversity's relationship with modern society encapsulated by terms like "assimilation" (cf. e.g. Alba and Nee, 2003, Glazer, 1993 and Lee and Bean, 2004) "hyphenation" (cf. Waters, 1990, on the one hand, with Alexander, 2001 and Parekh, 2006, on the other) and "integration" (see, e.g. Favell, 2001; Esser, 2004).

Some vagueness may be beneficial for the long-term survival of concepts like "multiculturalism" as a category of practice (Schall, 2014), but it makes the concept difficult to use as a category of analysis. Indeed, it is the very usefulness of 'multiculturalism' as a discursive category of practice, both for multiculturalism's enemies and for its friends that has distorted its usefulness as a category of analysis, becoming too normative and too easily distorted within political discourse for use in serious enquiry. Rather than try and reconstruct "multiculturalism" as a category of analysis, then, or to ascribe new analytical meanings to other categories of practice (as Faist, 2009, attempts to do with "diversity"), it may make more sense to approach diversity and society's relationship with diversity as a flexible, dimensional set of orientations. As such, I attempt to provide here a conceptual map of possible "types" of orientations towards diversity. Figure 1 lays out a conceptual map that takes into account two key dimensions of diversity discourses: (1) whether discourse is primarily concerned with the well-being of immigrants or of the host society, and (2) whether discourse is primarily about economic or cultural concerns. 
Figure 1: Mapping Diversity Discourses

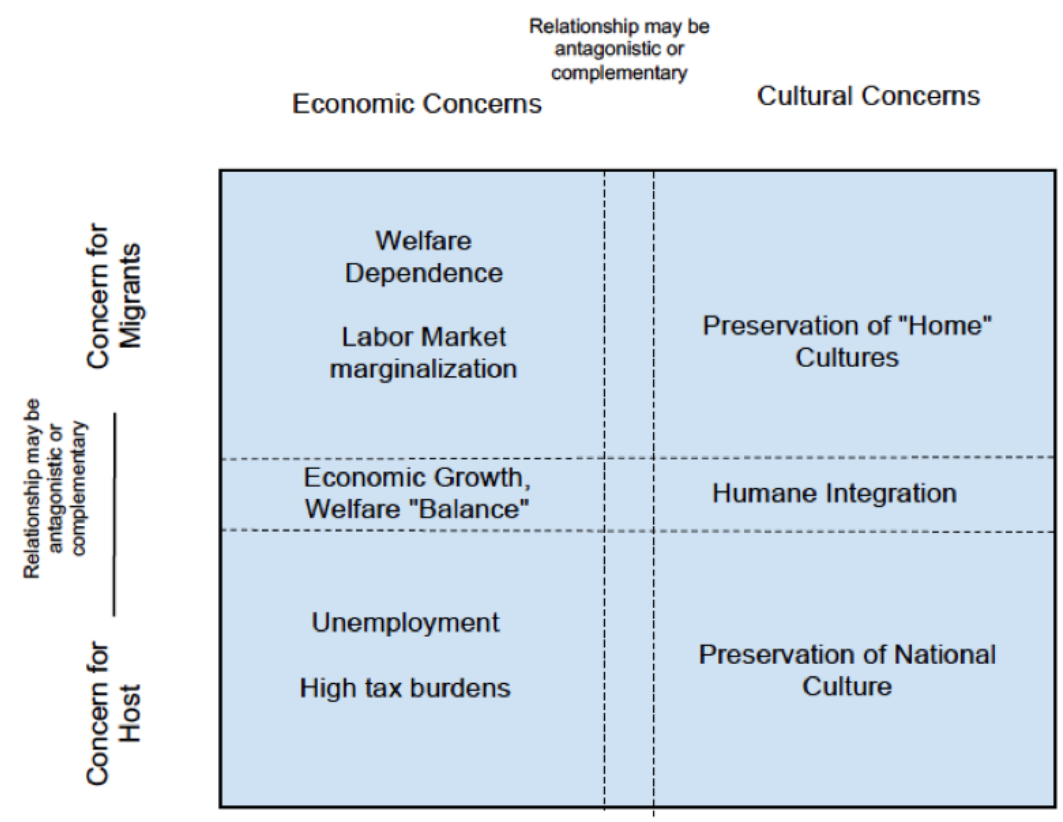

Discussions of diversity, particularly racial and ethnic diversity, are also improved by a careful separation of immigration discourse (who gets let into the country) and integration discourse (what states do once immigrants are in the country). Immigration and integration are, of course, closely dependent on one another. States with high or rapidly increasing immigration rates may differ systematically in the way integration is discussed from states with low or stable immigration rates. In particular, states with low immigration rates, may have almost no discourse on integration, or may have a discourse on integration that assumes assimilation as the only desirable outcome (as in Sweden before the 1960's, see, e.g. Wadensjö 1973). However, failure to analytically separate the two may make paradoxes where there are none. For instance, it is perfectly reasonable for unions to both advocate the restriction of immigration and to work to organize and get benefits for immigrants who are already in the country, as, for instance, AFSCME in the United States has done. Yet if we consider immigration and integration discourses as a sort of muddy amalgam, this seems like an inconsistent set of policy preferences (for more on this see Baumgart, 2011). Again, this points to the need to address and analyze discourses on diversity in a way that preserves complexity, and yet still provides sufficient guidance for analysis.

The separation of these two discourses something which is increasingly attended to explicitly in the literature on the cultural praxis of of immigrant incorporation (e.g. Bloemraad, 2006, 2008). Voyer (2013), for instance, illustrates how concerns in Lewiston, Maine about the absolute numbers of Somalis entering the town are transmuted into concerns over the cultural possibilities and perils of multiculturalism carefully analyzes these differences. Likewise Jaworsky (2013)'s exploration of boundary-making in a rapidly diversifying city looks at how concerns over mode of entry (legal vs. illegal) help to shape the moral boundaries people use to sort foreign-born people into insiders and outsiders. The productiveness of this analytical separation should lead us to favor more complex models of discourse on diversity. 
Note that all four "boxes" of the conceptual map above may be addressed from the perspective of immigration concerns or integration concerns, providing, perhaps a second axis along which one could place a particular discursive stance. Such a figure may be helpful primarily in identifying the particular features of a discourse, and the possible spaces for different "kinds" of discourse (ethical/pragmatic/moral).

\subsection{Data and Methods}

The case explored in this article is Swedish diversity discourses in two key time periods: 1968-1975 and 1991-1995. These time periods were chosen because they are periods of rapid shifts in discourse. The first time period represents a breakthrough period for discourse on diversity, where immigration became a central concern for both political actors and media actors alike, and where integration concerns begin to separate from immigration concerns in the public discourse (Schall, 2016). The second time period is a period sometimes characterized as a "refugee crisis," in both Sweden and elsewhere in Europe. It is further a period of drastic change in the Swedish party political landscape. Both periods, furthermore, represent numerical "peaks" in immigration rates. Both time periods also predate the arrival of popular anti-immigrant parties which have tended to control and distort the discourse on immigration, and thus the two periods. ${ }^{4}$ This makes them ideal cases in which to observe the way that discourse changes over time.

I rely on a qualitative analysis of newspaper articles from three newspapers with differing political slants: Arbetet (ARB), a Social Democratic newspaper, based in Malmö, Dagens Nyheter (DN), a Stockholm-based Liberal newspaper and Svenska Dagbladet (SvD), a Stockholm-based Conservative newspaper. All three of these papers are chosen for their large readership, as well as their status as relatively "mainstream" papers for their particular political slant. It should be noted that there were multiple newspapers associated with each of the three orientations, some of which were more radical than the three chosen (see Nord, 2001 for more on Swedish daily news). For the first time period, a hand-examination of every eighth issue of each newspaper was carried out. For the period 1991-1995, I used the database "BTJ ArtikelSök," which indexes major news outlets in Sweden, to search for relevant articles. Articles and editorials were selected using theory-driven purposive sampling. That is, articles and editorials were selected for their relevance to the research question (Miles and Huberman, 1994; Riffe and Freitag, 1997). Initially, all articles and editorials mentioning immigration or integration (though not necessarily immigrants) were included, but articles that made no claims about what should or should not be done about immigration and integration were ultimately excluded from the analysis.

Qualitiative analysis was carried out on all articles, using the $\mathrm{N}^{*}$ Vivo software package. The initial coding of text was carried out broadly by simply sorting passages into "moral," "ethical" and "pragmatic" categories. However, over the course of analysis, the coding structure was adjusted and refined throughout the coding process. All analysis was performed in Swedish and translation (by the author) was only carried out for the purposes of reporting. It is also important to recall that participants in these discourses are only sometimes consciously adopting a certain mode of argumentation, and, as such, a single actor may use a combination of two or three of them at the same time, or use a mode of argumentation that may legitimately be coded as more than one at the same time (i.e. ethical/pragmatic; moral/ethical). This paper, on the one hand, seeks to find dominant modes of argumentation and at the 
same time to preserve complexity. Thus, the coding structure reflects such ambiguities and multiplicities of meaning.

\section{Results}

\subsection{8-1975: From Pragmatic Problem Solving to Independent Ethi- cal Force}

Labor market immigration to Sweden had begun to rise in the mid-1950's and reached a high point in the late 1960's. By 1968, there were over 90000 people born outside of the Nordic countries (Sweden, Finland, Norway, Denmark and Iceland) residing in Sweden, approximately 1 percent of the Swedish population. An even larger number of Nordic migrants, mostly Finns, resided in the country. Migrants were drawn by high wages, plentiful work opportunities and relatively few restrictions on entrance for migrants who could secure work permits after arriving. Besides Finns, Western European (especially German) and Southern European (especially Yugoslavian and Greek) migrants made up the bulk of these labor migrants, though a significant Turkish migration also occurred. Migration slowed in the early 1970's, after changes in immigration law and during the oil crisis years when Sweden experienced relatively high unemployment.

While immigration did not immediately leap onto the front page following these increases in migration, discourses of diversity did spike after 1968 (Schall, 2016). The Liberals (Folkpartiet Liberalerna), a center-right party, and their newsprint counterpart, Dagens Nyheter led the way, particularly in its publication of a series of articles by a group of immigrant writers (some Liberals, others not), with Polish-Jewish immigrant David Schwarz in the fore. Schwarz, who came to be seen as the foremost "popular" expert on immigration at this time, and his cadre of writers were advocates, first and foremost, for the ideals of equality and cultural pluralism, but they were also interested in concrete policy recommendations (see Román, 1994; for DN's role in the upswing in diversity discourses, see Hulten, 2006).

It was the policy recommendations primarily that piqued the interest of political actors, and, indeed, much of the initial political discourse was pragmatic. The Social Democratic Party (SAP) and the blue-collar labor federation, the Landsorganisation (LO) in particular picked up modes of argumentation that focused on solving the "problem" of diversity. On the one hand, the LO and SAP at the beginning of this period were pragmatically in favor of immigration in favor of immigration in times of labor shortages: "many of our key industries are in need of labor, and there are many immigrants who wish to come here. This can be nothing but a mutually beneficial situation" (ARB 7/17/1968). On the other hand, there was a growing realization that discussions about immigration had to be separated from integration, and that immigrants would not simply assimilate if left alone. Rather, the LO and SAP had to take an active stance on integration - and that stance ended up being a pragmatic one.

It is likely that this was a response to wildcat strikes in heavily immigrant-employing northern mining towns in 1969 that forced SAP and LO to take up the issue of immigration in general. While it is unlikely that the largely Finnish immigrant population in these towns played much of a role in these strikes (see, e.g. Korpi, 1970; Yalcin, 2010), the public perception that the strikes were caused by immigrants who did not understand the norms and values of Swedish trade-union life provoked a reaction from SAP and LO. The reaction was to 
focus on recruiting immigrants into trade unions and the Social Democratic party. Björn Pettersson, first director of the LO's "Immigrant Council" (Invandrarrådet), for instance, argued that immigrants must be taught the "rules of the game" in order to stop "radical leftist groups from using immigrants as support troops in conflicts" with the mainstream union movement. ${ }^{5}$ LO, indeed, committed to providing translators and setting up "immigrant committees" for the express purpose of teaching immigrants how to be good union members (and perhaps, in the words of Wuokko Knocke (1981) to provide "a way for LO to avoid thinking about the specific problems of their immigrant members" p. 189).

This pragmatism extended to other policy areas. Lars Skiöld, a Social Democratic member of the Department of Education, for instance, argued that "the evidence shows that if we insist on only Swedish instead of bilingualism, these children will end up with a double-halflingualism (dubbel-halvspråkighet)" and that, therefore, "we must support home language education as a step on the way to Swedish." ${ }^{6}$ Home-language education was promoted because it was effective - not because it was the ethical or moral thing to do. Others argued pragmatically as well, though not always in the same direction as SAP and LO. Conservative Claes-Adam Wachmeister, for instance, argued that assimilation was the "only realistic way to turn immigrants into full-fledged citizens,"7 pointing out that, ethics and morals aside, other forms of integration were simply ineffective. Liberals, through the organ of DN, too, argued pragmatically that "immigrants must be included in the general welfare if we are to avoid social splits." 8

Yet, we can trace the beginnings of a moral/ethical mode of argumentation, as well. Tage Erlander, by then the retired leader of SAP, for instance, set immigrant rights in the context of a broader welfare-state ethics that pointed to the value of "individual self-realization" arguing that:

People want more collective measures, not just to advance the collective good, but also to increase possibilities for individual self-realization ... and new demands from minority groups who want a more equitable division of welfare and influence ought to be viewed in this light. ${ }^{9}$

Note that the policy suggested was the same as DN's above - full inclusion in the benefits of the welfare state - but the reasoning focused on what the "right" thing to do was in the context of Sweden as a welfare state. By the 1970's, too, an unsigned article in DN had made it plain that pragmatics were no longer the only justification for inclusion, but rather that inclusion was ultimately a matter of "justice and sound morals." 10 The home language policy argued for in such starkly pragmatic terms in the late 1960's, by the mid-1970's also was seen as a moral imperative, moving the discourse to a more general mode of reasoning. Home language policy was a road to cultural pluralism that would prevent a "spiritual death" as David Schwarz (1973) so forcefully put it. The ability for immigrants to choose how much and in what ways to integrate had become a constitutionally enshrined value (valfrihet, freedom of choice) by $1975 .^{11}$

In fact, it was the transition to an ethical mode of justification regarding integration that allowed for pragmatic talk of immigration restriction in the economically difficult oil crisis years of the mid-1970's. ${ }^{12}$ In fact, very few sought entry to Sweden in 1972 and 1973 (years with net emigration), but Palme and the LO's rhetoric about immigration continued to emphasize the need to get Swedes into jobs first. Indeed, the restrictive rhetoric continued even as the economy improved. The LO's 1975 report on labor shortages and immigration, 
for instance argued that "to use immigration to regulate short-term unevenness in demand on the labor market is extremely problematic" and "is detrimental to the Swedish labor market, sending-countries' labor markets, and, indeed, the immigrants themselves"13 While this talk is clearly pragmatic, it was predicated on a rejection of a "guest worker" model that was seen as unfair in its exclusion of immigrants from full equality. ${ }^{14}$ Indeed, Palme argued, too that "We cannot hide the fact that rapid and extensive immigration has created problems for us" and, therefore, immigration restriction was necessary in order to fulfill "our common responsibility to, together, create a better and more humane society" 15 This focus on the responsibility to maintain the equality of both immigrants and native-born Swedes was indicative of a moral boundary that tied a moral conception of humaneness to a pragmatic understanding of the limits of the Swedish labor market and welfare state.

Thus the rapid ascendance of diversity discourses in the late 1960's and early 1970's was characterized by a shift from pragmatic to ethical welfare state discourses and, finally, to moral egalitarian discourses. At the same time, the range of possible pragmatic "solutions" to diversity problems changed and expanded, as ethical commitments to integration were clarified and integration and immigration were increasingly seen as separate issues. It is notable, too, that the focus of this discourse was on outcomes for immigrants, rather than outcomes for the "host" nation, particularly in those cases when ethics were emphasized over pragmatics. It is this commitment to an ethical treatment of migrants (labor migrants in the $1960 \mathrm{~s} / 70 \mathrm{~s}$, refugees in the 1980s/1990s) that set the stage for the sort of "moral monopoly" of the 1990's to which this article now turns.

\subsection{1-1995: Moral Monopoly and its Discontents}

In the late 1980's and early 1990's Sweden was accepting refugees at an unprecedented rate. This new migration stood out from past migrations for two reasons. On the one hand, the sheer number of asylum-seekers was out of proportion to any previous waves of migration (although this would be dwarved by later waves of migration). At its peak, the acceptance of refugees reached 36,482 in 1993 and 44,875 in 1994 (about .4 percent and .5 percent of the Swedish population, respectively). A great many more seeking, but not receiving asylum. Family-reunification migration followed refugee migration by a year or two, making the number of total immigrants to Sweden in these years consistently high, despite the fact that labor market migration had fallen practically to zero by this time. On the other hand, these migrants were increasingly non-European, non-white and/or non-Christian. Besides former Yugoslavian migrants, many of whom were Bosnian Muslims, Iraqi Kurds, Iranians and Somalis made up the largest groups of asylum seekers and family-reunification migrants. This high rate of migration, the shift in sources of migrants from Western Europe to Eastern Europe, the Middle East and North Africa would come to be the "new normal," and so the 1990's can really be seen as the start of the current era of migration in Sweden, as it was for a great many countries in Europe.

By 1991, the discourse on immigration and integration had already shifted in a drastic way, one captured well by the following statement made by political scientist Jörgen Westerståhl:

Immigration policy is largely a taboo area in Swedish public debate...This silence is not based in the fact that opinions and interpretations of immigration don't exist. The silence is caused by the opinion-climate: A soon as someone gives an 
opinion that can be interpreted as restrictive, or gives reasons for and against in general, they run the risk of being labeled racist. And then all discussion ends. ${ }^{16}$

The pragmatism that had pervaded the earlier period had been all but replaced by a sort of moral monopoly that emphasized "generous" definitions of refugee status and multiculturalist integration policies. Indeed, the fear of being called "racist" or "xenophobic" seemed to hamper debate, particularly among elected officials (Schall, 2016; see also Odmalm, 2011).

Yet, many argued, correctly, that this restricted debate did not match up with the Swedish people's opinions about immigration. SAP member Bo Göransson, for instance, responding to a controversial anti-immigration article in the paper Expressen that:

Expressen got their facts wrong...But the critique against them was mainly moralizing. I am convinced that the majority of the Swedish people believe that Expressen was right, but that they weren't 'allowed' to be right: that the moral establishment kept Expressen from formulating their 'truths.' 17

Indeed, the early 1990's represented a time of 'loosening up' of diversity discourses. The coincidence of Sweden's most severe economic crisis since the 1930's with the so-called "refugee crisis" was behind this rapid change in both immigration and integration discourses. Increasingly, critics argued that Sweden was more interested in appearing to be, as Anders Fogelkou put it, "a moral great power" (moralisk stormakt) than in actually addressing the issue of immigration pragmatically. ${ }^{18}$ Linking this critique to a "rational," pragmatic accounting of immigrants' benefits to society, Alam and Host wrote that:

We have never really admitted that we need immigrants. We motivate our refugee acceptance with noble solidarity, tolerance and a general "feel sorry for" attitude. Because we've never admitted that we need immigrants, we've never been able to demand anything of them. ${ }^{19}$

Moral and ethical justifications were not totally discarded, but they were increasingly seen as inadequate. Birgitta Albons, for instance wrote that: "The only thing we stand together for is to make a reality everything that Sweden boasts about: Solidarity and human rights. But these should not be empty words." 20 At the same time, the focus of debate turned away from general moral statements and towards specific pragmatic ones, such as the following:

Many measures have been taken recently to improve the livelihoods of immigrants: language training, use of introductions and 'introduction stipends,' employment measures and immigrant internships. This is, however, far from sufficient. We need new, powerful measures directed at immigrants and a faster implementation of already passed measures. ${ }^{21}$

Demands to tally up the "real" costs of migration abounded, both in terms of the cost of the asylum process, and in terms of the cost/benefit analysis of immigrants participating in the labor market and welfare state long term. This indicated a renewed focus on problem-solving in the face of "new" problems having to do with both immigration and integration. ${ }^{22}$

While the victory of ethical (and ultimately moral) discourse over pragmatic discourse in the mid 1970's was predicated on a harmonization between the pragmatic solutions to 
"diversity" and the ethical requirements of a good welfare society, the mid-1990's return to pragmatism was motivated by the opposite - what was seen as "pragmatic" was often held to be, as Jesus Alcala so starkly pointed out, diametrically opposed to what was seen as "moral." Mauricio Rojas, for instance, argues that a position that was ethical in terms of the contextual factors of commitment to a welfare state and welfare state values, had "disastrous" practical consequences: "In the true spirit of the people's home (folkhem), the state has taken responsibility for immigrants' integration in society...But, oh! what great toil and spending of resources for such a disastrous result!" 23 Notably, Rojas is referring to the standardized full inclusion of immigrants into the "general solutions" of the welfare state precisely that "pragmatic" and "ethical" solution that was so praised in the previous period. Indeed, an increasingly vocal group argued that "multiculturalism is a utopia" 24 -in other words, something valuable and morally right, but impossible. While such an attitude to diversity was morally laudable, in practice, these critics argued, pursuing multiculturalism would result in the isolation of immigrants not only from native Swedes, but from the labor market, social services, and, in general, the high standard of living that had become the norm in Swedish society. ${ }^{25}$

Some did see pragmatic and moral/ethical concerns as matching up. Jan Malmborg, for instance, argued that the pragmatic evaluation of 'diversity' as inherently divisive was simply wrong; "We must convince the Swedish people that difference does not lead to division, but to change and development. Contact with other cultures is not always a "culture clash" (kulturkrock), but can be beneficial to all. ${ }^{26}$ Indeed, the idea that immigration restriction was the only possible pragmatic choice in the face of scarcity if one remained committed to ethical ideals like equality, resurfaced in this period. As political scientist Jose Alberto Diaz put it:

A country has a structurally limited integration potential. There are limits to how many people we can take in in a short time if they are to become equals (but still remain different) with the majority population. ${ }^{27}$

Others used the concept of a so-called structurally limited integration potential to point to the harm that taking in to many immigrants could do to the host country, arguing that "a country can only take in so many immigrants without creating imbalances in the economic system, society and social relations." Such a position was clearly, unambiguously pragmatic, signaling a return, at least in part, to a discourse allowing for the full range of ethical, pragmatic and moral justifications.

\section{Discussion}

A generalized narrative of the shifts in mode of argumentation overtime in Swedish diversity discourses looks something like this: Generalized immigration and integration discourse in the late 1960's began as primarily pragmatic, problem solving discourse that formed in reaction to well-publicized integration "problems,", but overtime the pragmatic solutions proposed for these initial problems acquired, first an ethical (welfare statist) and then moral (human rights) force that could roughly be equated with a sort of "proto-multiculturalism" or perhaps more accurately "humane integration." The separation of integration from immigration discourse allowed for pragmatic calls for immigration restriction that rested on an ethical understanding of integration policy as an arena for fighting inequality. By the late 1980's, 
the "moral and ethical force" that had begun to develop in the mid-1970's had been replaced by a collapsed moral-ethical distinction, leaving a taboo-laden "moral monopoly." Yet, in the face of severe crises - both a refugee crisis and an economic crisis - pragmatism returned to the center of the discourse on diversity. This pragmatism had a different character than the one that characterized the earlier in that pragmatic justifications were often (though not always) seen as antithetical to moral and ethical ones, and for many, these pragmatic concerns trumped ethical/moral ones. Drawing out this narrative gives us new insight into the research questions proposed at the beginning of this paper, and I turn to these now.

3.1. Question 1: What does the terrain of diversity discourses look like, both as a specific type of discourse and as an example of ethical, moral and pragmatic modes of argumentation?

What leverage, in this case, do we get out of considering 'diversity discourses' as dimensional, rather than as instances of a particular set of 'multiculturalist' or 'restrictive' utterances? For one, it allows us to separate out concern for host from concern for immigration in order to see how justifications for immigration restrictions in the first period, ethical concerns centered on preserving the rights of potential migrants themselves, differ from those in the second, pragmatic centered on the potential damage immigrants could do to Swedish society, despite continued moral beliefs around the human rights of migrants. For another, we can see where shifts in immigration concerns relative to integration concerns come to matter (and, indeed, where actor-confusion about the differences between these two sets of concerns matter). Thus, as a guide for classifying and understanding diversity discourses, a dimensional concept seems to be a productive tool for building narratives.

It should also be noted that there is a shift in the actors foregrounded in diversity discourses in the two periods, one that is mirrored in immigration discourse across Europe. The first period is characterized by a dominance of, on the one hand, politically unaffiliated immigrant writers pushing a particular cultural pluralist model of integration, and, on the other hand labor union officials and members of the reigning political party. The second time period is, on the other hand, is not dominated by a single group, but made up of members of multiple political parties and media actors with varying ties to the political process. The former set of actors may have a greater stake in narrowly focused "problem-solving" and a greater ability to control the content of the message than the latter set of actors. To restate in terms of the possible range of justificatory strategies, the first group may have had little incentive to push so quickly towards higher common ground moral claims in contrast to the political actors of the second time period.

\subsection{Question 2: What are the processes by which political discourses become "moral" or "ethical" and the processes by which such forms of ar- gumentation are "overridden" by pragmatics?}

Given the narrative sketched above, what, then enabled shifts from pragmatic through ethical concerns to moral monopoly and back to pragmatism? One important finding is that rather than ethical and moral justification necessarily being prior to politics, new ethical and moral orientations may arise out of post-hoc justifications of actions taken to solve particular problems (see Vaisey, 2009 for investigation of a similar phenomenon at the level of individual 
moral reasoning). For instance, the use of immigrant committees as a sort-of neutralizing force with the LO became re-articulated as a commitment to freedom of choice and cultural pluralism. This does not mean that the initial decision to form these committees was valuefree, but rather that the ethical commitments underlying the initial decision to form these committees (trade unionist values, solidarity among workers) were subsumed into "pragmatic" frames of references and the moral justifications for these actions ("cultural pluralism") only surfaced in the face of new problems. Similarly, the moral value ascribed to human rights, and the corollary ethical decision to treat immigrants as "members of society," especially a welfare society, rather than simply workers, created a space for justificatory reasoning that could legitimately claim that immigration restriction was both pragmatic and ethical - not only for the host country, but for the immigrants themselves. In both of these cases, the context of justification shifted such that level on which common ground could be found was different, and therefore both the meaning ascribed to actions and the possibilities of those actions shifted. While it is true, then, that morality sets the limits for legitimate debate, as Habermas predicts, the ways in which moral, ethical and pragmatic concerns intersect in particular justificatory contexts can color the contextual meanings of moral and ethical values such that an action that was "civil" in one case is "uncivil" (to use Alexander, 2006's terms) in another.

The answer to part two of this question also reveals an interesting feature of these types of discourse. At least in the case of diversity discourses in early 1990's Swede, pragmatic concerns overrode ethical and moral arguments in the face of severe crisis. It is notable that the refugee crisis of the late 1980's and early 1990's became a crisis not just of immigration, but one of integration - and it was in this arena of integration that we see the overriding process most clearly Neither the large number of asylum seekers itself, nor the increasing volume of immigration critics alone pushed pragmatic concerns to a higher priority than moral/ethical ones; it was that this "crisis" occurred in a discursive climate that was morally/ethically inflexible. Because of a moral monopoly that placed multiculturalism and generosity at the center, actors who wished to make drastic changes in light of the crises were forced to paint "pragmatic" solutions as antithetical to "moral" commitments. Discursive participants emphasized the pragmatic mode of justification, not in a way that harmonized with prevailing values (as in the previous period), but in a way, which explicitly, if sometimes reluctantly, abandoned them. ${ }^{28}$ To the extent that policy suggestions that strayed from the normative orientation towards diversity were justified with ethical language, that language pointed usually (though not always) towards ethical commitments to the host country, not to the immigrants themselves. Indeed, in general, we can conceptualize the role of pragmatic discourse under conditions of moral inflexibility as 'game changers.' Pragmatic discourses may serve to introduce or reintroduce ethical concerns that were previously ignored, therefore shifting the boundaries of previously set civil/uncivil (or ethical/unethical) binaries. Figure 2 illustrates this process.

The presence of these kinds of shifts in the past in regards to what is "practical" and what is ethical" opens up the distinct possibility that, eventually, moral boundaries may shift as well. The "new pragmatism" of the 1990s creates space for the articulation of of moral and ethical commitments that were in harmony with calls for immigration restriction and assimilationary integration policy. The growing dissatisfaction with the "moral monopoly" in this period indicates, at the very least, an increased acceptability for criticism of presumed universal moralities. 
Figure 2: Pragmatism and the shifting of civil/uncivil boundaries

Stable Condition 1: Pragmatic

reasoning unethical

Civil Uncivil

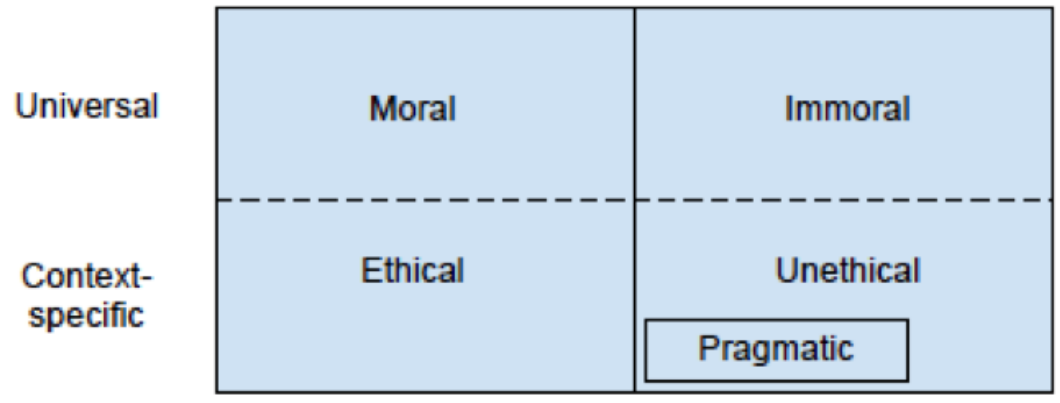

Unstable Condition. May be caused by weakening

boundaries, extreme crises or conflicting moral/ethical codes.

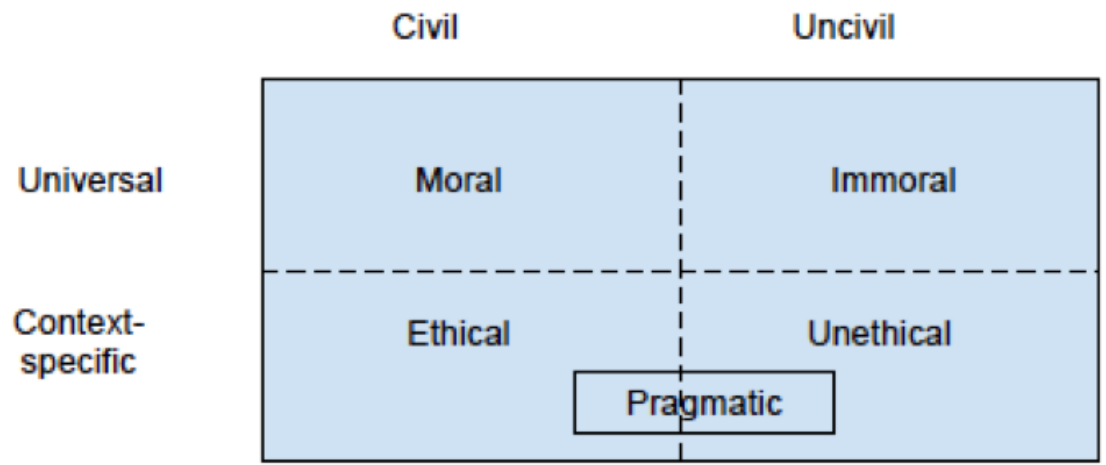

Stable Condition 2: Pragmatic reasoning ethical, shift in civil/uncivil (ethical/unethical) binary

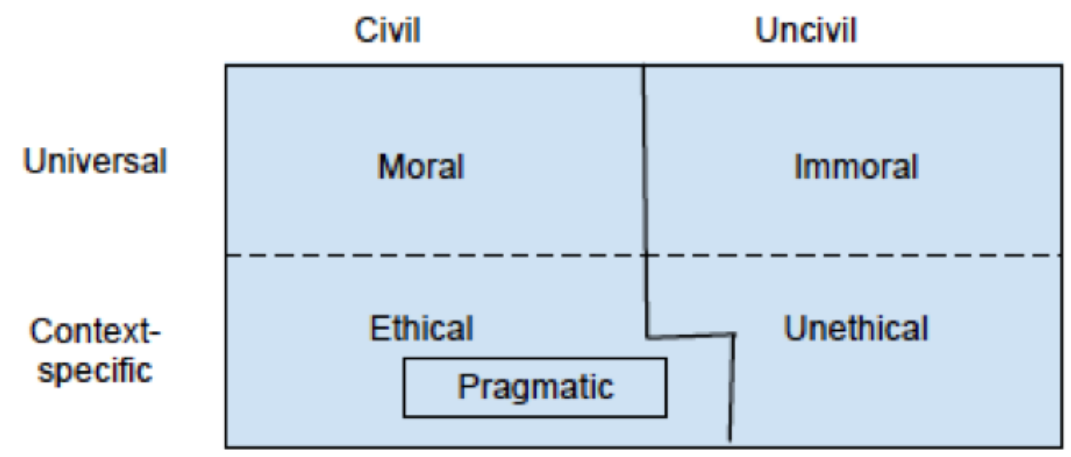




\section{Conclusions}

In fact, since 2006 or so, there has been an increasing political acceptability of antiimmigrant and anti-immigration rhetoric that is part of a deeper, more significant shift in diversity discourses. The astronomical rise of the Sweden Democrats, a far-right xenophobic party that was seen as morally reprehensible in the 1990's is the most visible manifestation of this, but the accommodation of mainstream parties to restrictive rhetoric and the shift of pro-immigrant activists towards anti-racist cultural work (see Schall, forthcoming) are also signs of changes in the justificatory contexts around diversity. The application of Habermas's typology to diversity discourses and the consideration of how his three types of reasoning shift in response to changes in justifactory contexts, thus, seems to provide some productive and novel insight. We can see, for instance, that ethical and moral values tend to enter politics at the interstices that arise when novel combinations of pragmatic, moral and ethical commitments arise. We can also see how the choice of modes of reasoning - and the shifts between levels of justificatory reasoning that Boltanski and Thevenot consider key to process of agreement - are determined by both past and present patterns of reasoning.

What, however, does this case say about the concerns that motivate Habermas's own examination of these types of justifications - concern for the communicative action that underlies democracy? This study finds, for instance, concrete evidence for the ways in which the presumed dominant morality of a society sets limits for legitimate debate in a democracy - particularly in the development of a "moral monopoly." However, at the same time, we see how that moral monopoly can be challenged via shifts in justificatory strategies in ways that can change the content of such "morality," reconfiguring presumed stable national moral repertoires (Skarpenes, Sakslind and Hestholm, 2016). This is akin to Alexander (2006)'s process of civil repair whereby it is not just people who are reclassified as civil or uncivil, but the meanings of civility, and hence, societal membership change. The increasing civility of restrictivist discourse on migration may make it harder for migrants to become part of the Swedish democratic community.

Likewise, ethical concerns can be mobilized in multiple ways, and are neither always prior to nor always post to either morality or pragmatism. This demonstrates the ways in which ethical plurality (a condition of modernity, as Habermas points out), may indeed be necessary to democracy, not only because democracy by definition entails the tolerance of multiple ideas, but because ethical pluralism, and the pragmatic and moral shifts that both proceed and follow ethical plurality may create spaces for the entrance of new justifications of all three types.

\section{References}

Abend, Gabriel. 2008. Two main problems in the sociology of morality. Theory and Society, 37(2), pp.87-125.

Alba, Richard D., and Victor Nee. 2003. Remaking the American Mainstream: Assimilation and the New Immigration. Cambridge, MA: Harvard University Press.

Alexander, Jeffrey C. 2001. Theorizing the "Modes of Incorporation": Assimilation, Hyphenation, and Multiculturalism as Varieties of Civil Participation. Sociological Theory, 19(3), 237-249. doi: 10.1111/0735-2751.00139

Alexander, Jeffrey C. 2006. The Civil Sphere. Oxford: Oxford University Press. 
Baumgart, Zachary. 2011. "No reform would move without a united labor front": using unity to reconcile with variation in immigration discourse within American labor unions. University of Wisconsin: Unpublished Master's Thesis.

Benford, Robert D., and David A. Snow. 2000. Framing processes and social movements: An overview and assessment. Annual Review of Sociology, 26(1), 611-639.

Bentham, Jeremy. 1907. An Introduction to the Principles of Morals and Legislation.Oxford: Clarendon Press.

Berezin, Mabel. 1997. Politics and Culture: A Less Fissured Terrain. Annual Review of Sociology, 23(1), 361-383. doi: 10.1146/annurev.soc.23.1.361

Björkdahl, A. (2007). Swedish norm entrepreneurship in the UN. International Peacekeeping, 14(4), 538-552.

Boltanski, Luc, and Laurent Thevenot. 2006. On justification: Economies of worth. Vol. 27. Princeton University Press.

Boltanski, Luc., and Laurent Thevenot, 1999. The sociology of critical capacity. European journal of social theory, 2(3), 359-377.

Cooke, Maeve. 1997. Authenticity and Autonomy: Taylor, Habermas, and the Politics of Recognition. Political Theory, 25(2), 258-288. doi: 10.1177/0090591797025002005.

Esser, H. 2004. Does the "New" Immigration Require a "New" Theory of Intergenerational Integration? International Migration Review, 38(3), 1126-1159. doi: 10.1111/j.17477379.2004.tb00231.x.

Faist, Thomas. 2009. Diversity - a new mode of incorporation? Ethnic and Racial Studies, 32(1), 171-190. doi: 10.1080/01419870802483650.

Favell, Adrian. 2001. Philosophies of Integration: Immigration and the Idea of Citizenship in France and Britain. Houndmills, Basingstoke, Hampshire: Palgrave in association with Centre for Research in Ethnic Relations, University of Warwick.

Glazer, Nathan. 1993. "Is Assimilation Dead?" Annals of the American Academy of Political and Social Science 530: 122-136.

Hansen, Lars-Erik. 2001. Jämlikhet och valfrihet: en studie av den svenska invandrarpolitikens framväxt. Stockholm: Almqvist and Wiksell International.

Habermas, Jurgen. 1993. Justification and application: Remarks on discourse ethics. Cambridge, MA: MIT Press.

Habermas, Jurgen, 1994. Struggles for Recognition in the Democratic Constitutional State. In A. Gutmann (Ed.), Multiculturalism: Examining the politics of recognition. Princeton, NJ: Princeton University Press.

Habermas, Jurgen. 1996. Between facts and norms: Contributions to a discourse theory of law and democracy. Cambridge, MA: MIT Press.

Heilbroner, Robert L. and William S. Milberg. 1995. The crisis of vision in modern economic thought. Cambridge, MA: Cambridge University Press.

Hulten, Gunilla. 2006. Främmande sidor: främlingskap och nationell gemenskap i fyra svenska dagstidningar efter 1945. Valdemarsvik, Sweden: Akademitryck.

Jaworsky, B. N. (2013). Immigrants, aliens and Americans: Mapping out the boundaries of belonging in a new immigrant gateway. American Journal of Cultural Sociology, 1(2), 221-253. 
Knocke, Wuokko. 1981. Invandrare möter facket: betydelse av hemlandsbakgrund och hemvist $i$ arbetslivet: forskningslägesrapport kompletterad med intervjuer. Stockholm : Arbetslivscentrum

Korpi, Walter. 1970. Varför strejkar arbetarna? Stockholm: Tiden.

Kymlicka, Will. 1995. Multicultural Citizenship: A Liberal Theory of Minority Rights. Oxford: Oxford University Press.

Laitin, David D. 1986. Hegemony and Culture: Politics and Religious Change among the Yoruba. Chicago: University of Chicago Press.

Lee, Jennifer, and Frank D. Bean. 2004. "America's Changing Color Lines: Race/Ethnicity, Immigration, and Multiracial Identification." Annual Review of Sociology 30:221-242.

Miles, Matthew B. and A. Michael Huberman. 1994. Qualitative Data Analysis: An Expanded Sourcebook. Thousand Oaks, CA: Sage.

Nord, Lars. 2001. Vår tids ledare : en studie av den svenska dagspressens politiska opinionsbildning. Stockholm: Carlssons förlag.

Odmalm, Pontus. 2011. Political Parties and 'the Immigration Issue': Issue Ownership in Swedish Parliamentary Elections 1991-2010. West European Politics. 34(5): 10701091. doi: 10.1080/01402382.2011.591098.

Parekh, B. (2006). Rethinking multiculturalism: Cultural diversity and political theory. (2nd ed.). Basingstoke: Palgrave Macmillan.

Riffe, Daniel and Alan Freitag. 1997. A Content Analysis of Content Analyses: TwentyFive Years of Journalism Quarterly. Journalism and Mass Communication Quarterly. 74(3): 515-524.

Riley, Dylan. 2010. The civic foundations of fascism in Europe: Italy, Spain, and Romania, 1870-1945. Baltimore: John Hopkins University Press.

Riley, Jonathan. 1990. "Utilitarian Ethics and Democratic Government." Ethics 100(2): 335-348.

Román, Henrik. 1994. En invandrarpolitisk oppositionell: Debattören David Schwarz syn på svensk invandrarpolitik åren 1964-1993. Uppsala, Sweden: Uppsala Multiethnic Papers.

Schall, Carly Elizabeth. 2014. "Multicultural Iteration: Swedish National Day as Multiculturalismin-Practice." Nations and Nationalism, 20(2), 355-375.

Schall, Carly Elizabeth. 2016. The Rise and Fall of the Miraculous Welfare Machine: Nation, Immigration and Social Democracy in 20th Century Sweden. Ithaca, NY: Cornell University Press.

Schall, Carly Elizabeth. Forthcoming. Racist Resurgences and Old/New Left Hegemonies: How the Anti-Racist Left Makes Space for the Far Right in Sweden and the United States. in Managing Multicultural Scandinavia. Madison, WI: University of Wisconsin Press.

Schwarz, David. 1971. Svensk invandrar- och minoritespolitik, 1945-1968. Stockholm: Prisma.

Skarpenes, Ove, Rune Sakslind, and Roger Hestholm. "National Repertoires of Moral Values." Cultura 13.1 (2016): 7-27.

Swidler, Ann, 1986. Culture in action: Symbols and strategies. American Sociological 
Review, pp.273-286.

Tavory, Iddo. 2011. The Question of Moral Action: A Formalist Position. Sociological Theory. 29(4): 272-293. doi: 10.1111/j.1467-9558.2011.01400.x

Taylor, Charles. 1994. The Politics of Recognition. In A. Gutmann (Ed.), Multiculturalism: Examining the politics of recognition. Princeton, NJ: Princeton University Press.

Vaisey, Stephen. 2009. Motivation and justification: A dual-process model of culture in action. American Journal of Sociology, 114(6), pp.1675-1715.

Voyer, Andrea M., 2013. Strangers and neighbors: Multiculturalism, conflict, and community in America. Cambridge University Press.

Wadensjö, Eskil. 1973. Immigration och samhällsekonomi. Studentlitteratur, Lund.

Waters, Mary. 1990. Ethnic Options: Choosing Identities in America. Berkeley: University of California Press.

Weber, Max. 1949. The methodology of the social sciences. (E. Shils, Trans.). Glencoe Ill.: Free Press.

Yalcin, Zeki. 2010. Facklig gränspolitik: Landsorganisationens invandrings- och invandrarpolitik 1946 - 2009. Örebro, Sweden: Örebro Universitet.

\section{Notes}

\section{${ }^{1}$ DN 08/13/1993}

${ }^{2}$ This paper does not attempt to disentangle what is truly "moral" versus what merely makes claims towards morality. As Tavory (2011) points out, this approach has its dangers, and, indeed, greater focus on "moral action" in this way is probably needed. Yet for our purposes, we are mainly interested in the mere presence of moral, ethical and pragmatic claims, not the truth or validity of the content of these claims.

${ }^{3}$ Vaisey, 2009 makes this point about motivation as opposed to justification in individual moral reasoning, arguing that most individuals cannot articular clear moral principles to explain their motivation for actions, but that post-hoc justifications that draw on moral scripts do have an effect on later actions.

${ }^{4}$ Of course, New Democracy, a far right party became popular in the 1990s, but its breakthrough was around issues of tax revolt primarily and began to move towards obscurity when it turned towards immigration as an issue (see Schall, 2016).

${ }^{5}$ Petersson, Invandrarrådets 1:a sammandträdet, 01/11/1973

${ }^{6}$ Lars Skiold (SAP) qtd in DN 1/9/1968

${ }^{7} \mathrm{DN}$ 03/16/1968

${ }^{8}$ DN 08/14/1969

${ }^{9}$ qtd in ARB 12/27/1972

${ }^{10}$ DN 09/15/1971, see also DN 08/10/1973 for statement about "equal treatment of people regardless of race, religion or ethnic origin."

${ }^{11}$ One presaged by Schwarz's repeated refrain that "the right to equality included the right to be different" (a phrase that originates in DN 02/25/1966, but recurs frequently in Schwarz's writings, see Román, 1994.); On the constitutional enshrinement of "equality and freedom of choice," see Hansen, 2001 and Schall, 2016.

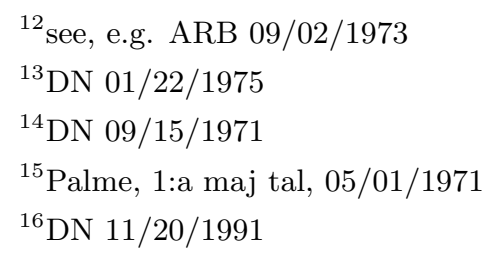


${ }^{17} \mathrm{DN} 10 / 16 / 1993$

${ }^{18} \mathrm{DN} 08 / 07 / 1992$

${ }^{19}$ DN 7/5/1992; see also Söderberg ARB 04/13/1993

${ }^{20}$ ARB 05/05/1992

${ }^{21}$ Begler, Mossler and Bergström DN 09/19/1995

${ }^{22}$ e.g. SvD 05/13/1991; SvD 09/18/1994; DN 07/11/1992

${ }^{23} \mathrm{DN} 11 / 11 / 1992$

${ }^{24} \mathrm{DN} 07 / 02 / 1993$

${ }^{25}$.g. SvD 09/22/1993; SvD 08/13/1993

${ }^{26}$ ARB 06/13/1994

${ }^{27}$ qtd in Lilian Öhrström DN 07/02/1993

${ }^{28}$ Note that not all who saw morality and pragmatism as opposed chose pragmatism. Jesus Alcala, whose quote opens this article, for instance, emphatically comes down on the side of what he calls "morality."

\section{Affiliation:}

Carly Elizabeth Schall

Indiana University Purdue University Indianapolis

Indianapolis, Indiana 46202

E-mail: cschall@iupui.edu 